\title{
Vepsa küla traditsioonilised pühad 20. ja 21. sajandi vahetusel
}

\author{
Irina Vinokurova
}

Teesid: Käesolev artikkel käsitleb vepsa rahva tänapäevast etnokultuuri ja analüüsib, milline on pärimuse võimalik mõju vepsa rahva säilimisele. Sotsialismi tingimustes mõjutasid vepslaste, nagu ka teiste rahvaste traditsioonilist pühadesüsteemi igapäevaellu tungivad uued sotsiaalsed suhted, mistõttu senine pühadesüsteem sattus väljasuremisohtu. Artikkel annab ülevaate vahepealsestest mõjudest ning pakub mõnes vepsa külas tänini peetavate Issandamuutmise pühade (spas) ja makabeipäeva tähistamise analüüsi näitel ülevaadet vepsa tõotus- ja patroonipühade praegusest seisust, nende funktsioonist ja arenguvõimalustest.

Märksõnad: Issandamuutmise püha, kalendrikombestik, makabeipäev, vepsa

Käesoleva artikli teema tuleneb vepsa rahva tänapäevasest etnokultuurilisest olukorrast: ühest küljest vepslaste ja vepsa keele kandjate arvu kiirest vähenemisest, teisest küljest suurenenud rahvuslikust eneseteadvusest, eriti põhja-vepsa noorte seas, ning püüdlusest taaselustada kultuuriline ja keeleline pärand ning õigeusu vaimne maailm. Vepsa rahva säilimise juures võivad traditsioonilised pühad (esmajoones tõotus- ja patroonipühad) etendada tähtsat rolli. Tuletagem meelde, et minevikus olid need rahvusliku kasvatuse ja rahva ühtseks vaimseks tervikuks liitmise võimsad institutsioonid, mis kontrollisid vepsa territooriumil religioosseid, majanduslikke, 
sugulus- ja peresidemeid (Vinokurova 1998: 99-118). Praeguseks on tõotus- ja patroonipühad vepslaste igapäevaelust peaaegu kadunud. Ainult Leningradi ja Vologda oblastis on säilinud mõned "elava vanavara pulseerivad saarekesed".

Mõnes vepsa külas tänini tähistatavate augustikuiste Issandamuutmise pühade (spas) tsükli analüüsi näitel pakutakse selles artiklis ülevaadet vepsa tõotus- ja patroonipühade praegusest seisust, nende funktsioonist ja arenguvõimalustest.

Artikli aluseks on järgmised välitööde materjalid Vologda oblasti Babajevo rajooni (Kuja ja Päžaŕ) ning Leningradi oblasti Boksitogorski rajooni (endise Pölo pogosti asulad) aladel ${ }^{1}$ :

a) autori poolt magnetofonilindile ja päevikutesse salvestatud vestlused informaatoritega neis paigus kahel korral - aastail 1981-1983 ja 20 aastat hiljem, aastail 2001-2002;

b) pühade videosalvestused aastaist 2001-2002, mida filmis Karjala keele, kirjanduse ja ajaloo instituudi insener V. Bovin kompleksekspeditsioonide käigus. ${ }^{2}$ Videokaamera kasutamine andis võimaluse talletada paljusid pühadel esinevate nähtuste olulisi detaile, mis võivad küsitlemise ajal tähelepanuta jääda.

\section{Traditsioonilise pühadesüsteemi muutumine nõukogude ajal}

Püstitatud ülesannete täitmine on lahutamatult seotud vepslaste pühadesüsteemi muudatuste protsessi analüüsiga kogu nõukogude aja vältel, alates 1917. aastast ja lõpetades praeguse ajaga.

Sotsialismi tingimustes mõjutasid vepslaste, nagu ka teiste rahvaste traditsioonilist pühadesüsteemi igapäevaellu tungivad uued sotsiaalsed suhed. Pühadesüsteem kaotas üha rohkem oma terviklikkust ja ilmnes üldine väljasuremistendents. Selle käik ei olnud kõigil aastatel siiski ühesugune. Vepsa traditsiooniliste pühade muutumist on mõjutanud neli tinglikku perioodi Venemaa 20. sajandi ajaloos:

1. Suur Sotsialistlik Oktoobrirevolutsioon (1917), mis pani aluse põhjalikele muudatustele külas;

2. 1920.-1930. aastad, mil hävitati üksikmajapidamised, kollektiviseerimise algus, äge võitlus religiooniga;

3. 1950.-1970. aastad - ateistliku võitluse jätkumine, pühakodade ja kabelite kadumine; külaelanike massiline migratsioon linnadesse, mitmete "mitteperspektiivsete" külade likvideerimine; 
4. 1990. aastad - üleminek kapitalistlikele suhetele, õigeusukiriku taassünd ja legaliseerimine Venemaal.

Nõukogude võimu esimesel aastakümnel, seega esimesel perioodil, vepsa talupoegade traditsiooniline olme ja sellega seotud pühad peaaegu ei muutunud. Sellise järjepidevuse üks põhjusi oli seniste eratalumajapidamiste jätkuv püsimine, mis aitas säilitada traditsioonilist mõtteviisi (Tultseva 1985: 14). Samal ajal hakkasid uued revolutsioonilised ümberkorraldused tungima vepsa talurahva ellu. 1920. aastate alguses Kuja ja Pondala vepslaste (Vologda oblasti Babajevo rajoon) juurde sattunud N. Morev iseloomustas traditsioone ja uuendusi vepsa olmes järgmiselt: "tšuharite küla on ka tänapäeval kahe maailma, kahe ellusuhtumise võitlustanner" (Morev 1924: 46).

Üks revolutsioonilisi ümberkorraldusi puudutas riigi suhtumise muutumist religiooni ja kirikusse. Lenin ja teised bolševismi ideoloogid olid fanaatiliselt veendunud religiooni kokkusobimatuses kommunistliku formatsiooniga. Venemaal kehtestatud nõukogude võim, mis kuulutas maailmas esimese klassivaba ja ateistliku riigi loomist, paiskus koheselt kiriku kallale repressiivsüsteemi täie jõuga. Tuntud filosoof L. Mitrohhin toob välja selle kaks tegutsemissuunda: esiteks uute seaduste vastuvõtmine, mis lõhkusid kiriku olemasolu aluseid, teiseks regulaarselt kirikuvastase võitluse meetmeid käsitlenud ja repressiivset infrastruktuuri juhtinud poliitbüroo arvukad, peamiselt rangelt salajased instruktsioonid, konkreetsed lahendused ja näpunäited, kus otsustavat rolli mängisid Ülevenemaaline Erakorraline Komisjon $(B Ч K)$ ja Ühendatud Riiklik Poliitvalitsus (ОГПУ), justiitsministeerium, revolutsioonilised sõjakomiteed ja tribunalid ning eriti salajane poliitbüroo religioonivastase võitluse komisjon (1922-1929) (Mitrohhin 2005: 193). Dekreedi "Kiriku riigist ja kooli kirikust eraldamisest" vastuvõtmisega 1918. aastal (NVD 1957: 371-374) algas külades ateistlik võitlus, mida viisid rahva seas jõhkrate administratiivsete meetoditega läbi partei ja nõukogude aparaadi töötajad, kooliõpetajad ja kohalikud sõjakalt usuvastased elanikud. See sai tõukeks õigeuskliku kihistuse väljatõrjumisel traditsioonilisest pühadesüsteemist. Siiski jäi suurem osa vepsa elanikkonnast sel perioodil sügavalt usklikuks ja järgis õigeusu kombetalitusi. Eriti puudutas see naisi. N. Morevi ülevaatest nähtub, et pärast revolutsiooni usklike hulk meeste seas kahanes, naiste religioossus jäi aga endisele tasemele. Külastades Jumalaema Uinumise tõotuspühal Vologda oblasti Prangati külas (Kuja) kirikut, 
märgib Morev: kui enne revolutsiooni oli patrooni- ja tõotuspühade ajal kirikus kitsas, siis nüüd "oli vasak pool kirikust täis naisi alates 80aastastest eidekestest ja lõpetades noorukeste kirjude sitsrätikute ja -sarafanidega tüdrukutega, parem pool oli tühi, umbes kümmekond ätti surus end orvu kombel vastu seinu, justkui häbenedes oma väikesearvulisust" (Morev 1924: 48). Õigeusutraditsioonide püsivusest annavad tunnistust Z. Malinovskaja materjalid Ojati vepslaste kohta 1920. aastatest, kes tolle aja vaimus kirjutab, et kohalikud elanikud jätkavad endiselt lähimate pogostite ja kabelite külastamist, kusjuures kohalike kombel väljendudes "Korvoili minnakse kõrvade pärast, Nemžile kolmekäelise Jumalaema juurde käte pärast, Ladvas käiakse Korsuni Jumalaema ikoonile antud lubaduse pärast, Mirginitšis Ojati jõe ääres samuti lubaduse tõttu jne" (Malinovskaja 1930: 199).

Kollektiviseerimise algusega vepsa traditsiooniliste pühade ja kombestiku transformeerumine süvenes. Tekkinud kolhoosidel ei lubatud lähtuda traditsioonilisest põllumajanduslikust rahvakalendrist, mis põhines pühakupäevadel, mis varem oli talurahva majanduselu ja pühade arvestuse olulisimaid tähiseid. Järjest enam hakkasid põllutööde tähtaegu esitama kõrgemalseisvad võimuorganid, kes meelega ignoreerisid õigeusu pühasid ja nende töökeelde pühadel päevadel.

1930. aastatel võttis religioonivastane võitlus riigis veelgi karmima kuju. Sellele aitas kaasa 15. mail 1932. aastal vastu võetud Stalini allkirjaga valitsuse dekreet "jumalata viisaastaku" kehtestamise kohta, mille eesmärk oli Jumala nime täielik unustamine riigis 1. maiks 1937. Usuvastast võitlust hakati külades läbi viima forsseeritud tempos ja see võttis üha halastamatumaid vorme. Nagu kinnitavad vepslaste jutud, võrdsustati just neil aastail paljud vaimulikuseisuse esindajad rahvavaenlastega ja represseeriti. Sellest ajast peale kadus vepsa küladest selline sotsiaalne roll nagu vaimulik, olemast lakkasid mitmed kombetalitused, mida viisid läbi vaimulikud - ristikäigud, palvused jne. Kirikupühi tähistavad inimesed riskisid tagakiusamise alla sattumise ja trahvidega (Karjala teaduskeskuse arhiiv, f 1 , op 6 , nr 109, lk 1).

Antireligioosset propagandat ja agitatsiooni läbi viies sulgesid ateistid usklike tahte vastaselt kirikuid. Inimeste tundeid naeruvääristades seati neis sisse laoruume või klubisid, lõhuti kabeleid. Nii hävisid sel ajal paljud arhitektuurilise ja kunstilise väärtusega kultusmälestised. Barbaarselt hävitati mitte üksnes kirikuid, vaid ka 
tegutsevaid kalmistuid nende ümber. 1989. aastal olime tunnistajaks, kuidas Leningradi oblasti Podporožje rajooni Ladva ja Mägäŕve asulas külastasid vanad inimesed klubide (endiste kirikute) läheduses surnud vanemate ja sugulaste mahatallatud haudu, mida kõige aktiivsemad jumalavastased veel 1930. aastatel maatasa tegid. Seoses pühade paikade hävitamisega on vepsa elanikkonnal palju pärimusi. Neis räägitakse reeglina jumalavallatule osaks saanud karistusest. Näiteks Leningradi oblasti Podporožje rajooni Viĺhali külanõukogu ${ }^{3}$ juures oleva kivi (pühakoha nimi on Peštor) juurde ehitatud kabeli kohta räägiti järgmist: "Brigadir nõudis kogu aeg, et kabel lammutataks. Selle eest kaotas ta jalad, ja ta roomas põlvedel Mikola ees (kivist kujusse paigutatud ikoon - autor) ja palus andestust" (Karjala teaduskeskuse arhiiv, f 1, op 50, nr 985, lk 31). V. Ravdonikas kinnitab, nagu oleks Ladvas kirik suletud kokkuleppel kohaliku elanikkonnaga (Ravdonikas 1926: 20). Kuid meie küsitlus näitas, et seda tehti usklike tahte vastaselt (Karjala teaduskeskuse arhiiv, f 1, op 6, nr 106, lk 6). Sama kinnitavad ka Ladva eakate informantide jutud sellest, et inimene, kes murdis Jüri kiriku risti, jäi kätest ilma (Karjala teaduskeskuse arhiiv, f 1, op 6, nr 106, lk 7).

Kuigi religiooni mõju vepsa elanikkonnale on võrreldes revolutsioonieelse ajaga järsult kahanenud, oli see Suure Isamaasõja eel ja ajal ning esimestel sõjajärgsetel aastatel ikka veel märkimisväärne (Stepanov 1986: 3). Enne "jumalavaba viisaastaku" lõppu viidi elanikkonna seas läbi massiküsitlus, mille tulemused olid piinlikkusttekitavad kaks kolmandikku külaelanikkonnast ja üks kolmandik linnaelanikest osutus avalikult usklikeks (Tšugunova 1989: 27). Osutus võimatuks korraldada viie aastaga ümber sajandite vältel kujunenud õigeusklik maailmavaade.

1930.-1940. aastatel rajasid kohalikud vepsa külades varasemate vanade kabelite kohale sageli uued - tavalised puithütid, kuhu toodi päästetud ikoonid, ikoonilambid, vahaküünlad. Sellistes kabelites käidi endiselt igasuguste hädade vastu antud tõotuse pärast. Hädade teket seostasid inimesed sageli pühade traditsiooni hävitamisega ning nõudsid selle taastamist ja avalikku patukahetsust. Nii säilis Kiĺkili (Korvoiĺ) külas peetripäeva traditsioon 1930. aastate lõpuni. ${ }^{4}$ A. Medvedjeva, kes 1938. aastal oli 60aastane, teatas, et veel enne tema meheleminekut lakkasid inimesed tähistamast peetripäeva. Seejärel tabas kariloomi hukkasaamine. Siis nõudsid vanemad inimesed, et 
peetripäeval kari taas igal aastal rituaalselt piirataks. Informandi sõnade kohaselt lõppes kadu kohe, kui püha oli taastatud (Peeter Suure nimelise antropoloogia ja etnograafiamuuseumi arhiiv, f 13, op 1 , nr $6,1 \mathrm{k} 87$ ).

1950. aastad kuuluvad vepslaste traditsioonilise pühadesüsteemi hääbumise tee kolmanda perioodi algusse. Neil aastail algas erinevatel sotsiaalmajanduslikel põhjustel vepsa külaelanikkonna järsk vähenemine, peamiselt linnadesse suunduva migratsiooni arvel. Migratsioon puudutas külaelanike kõiki vanuserühmi, kuid eriti tugevalt olid sellest haaratud 20-29aastased noored (Birin 1989: 48). 1960.1970. aastatel, paljude "mitteperspektiivsete" külade likvideerimise ajal, suurenes (ennekõike noorte) vepslaste väljavool küladest veelgi (Birin 1989: 49). Uuringute kohaselt kõikus 1983. aastal 16-29aastaste noorte osatähtsus vepsa külades 9-36\% vahel (Strogalštšikova 1989: 36-37). Need andmed annavad tunnistust põlvkondadevahelise traditsioonilise kultuuri (eriti pühadepärimuse) edasiandmise häiritusest. 1950. aastate lõpust ei leidnud allesjäänud (kuigi tugevate moonutustega säilinud) traditsioonilised pühad, mida oli aastasadu põlvest põlve edasi antud, enam noorte seas edasikandmist. Praegu elab vepsa külades noori juba üsna vähe, eriti tüdrukuid. Sotsioloogide hinnangul on täheldatav sugude disproportsioon: peigmeeste ülejääk ja pruutide puudus, mis raskendab perede loomist, mida väljakujunenud abieluinstitutsioonidega pärimusühiskonnas ei esinenud.

Koos paljude vepsa külade kadumisega lakkasid toimimast ka varasemad pühadepõhised sidemed. Selliste oluliste asulate nagu Šimǵäŕ, Nažamjäŕv ja Vahtaŕ hävitamine lõhkus traditsioonilised pühadepidamissidemed liinil Šimǵäŕ - Nažamjäŕv - Ladv (42km) ja Päžaŕ - Vahtaŕ - Ladv - Järved (60 km) (Petuhhov 1989: 55). Selliseid näiteid võib tuua palju.

\section{Makabeipäev 20. sajandil ja 21. sajandi alguses}

2001. aastal said meie kompleksekspeditsiooni liikmed iga aasta 14. augustil tähistatava makavan päiva vahetuteks osalisteks Vologda oblasti Babajevo rajooni Kuja külastus, 2002. aastal aga endises Pölo pogostis Leningradi oblasti Boksitogorski rajoonis. Mõlemad olid tõotuspühad, mis tekkisid karjakaotuse tagajärjel. Nagu teada, on 14. august (vkj 1. august) õigeusukalendris väga oluline päev. Kirik- 
likus pärimuses on see pühendatud Issanda ristipuu väljatoomisele ja Kõigearmulisema Päästja ja Püha Jumalaema austamisele, samuti seitsme Makabei märtri mälestamisele. Talupoegadel, eriti Venemaa kesk- ja lõunaosas, on see püha seotud kirikus pühitsetavate puuviljade korjamisega. Sellest ajast algab kahenädalane Jumalaema Uinumise paast.

Esimest korda kogusin makabeipäevaga seotud materjali Valgejärve ja lõunavepslastelt aastail 1981-1983. Sel ajal olid minu informantideks peamiselt 20. sajandi alguses sündinud inimesed. See tähendab, et nõukogude võimu kehtimahakkamiseks, mil traditsiooniline pühadesüsteem ei olnud veel hävitatud, olid nad umbes 10aastased ja pisut vanemad - see on iga, mil inimene suudab sündmusi meelde jätta. Selle põlvkonna informantide mälu oli talletanud makabei päeva püha kõige tähtsamad kombetalitused (Karjala teaduskeskuse arhiiv, f 1, op, 50, nr 674, lk 1-4; f 1, op 50, nr 677).

Minevikus kogunesid Kuja külastu kolme küla (vepsa külad Kiino ja Prangat ning umbes 20. sajandi teisel poolel venestunud Sontag) elanikud kabeli juurde, mille lähedal asusid Sornova järv ja kalmistu. Kabeli juurde aeti hobused ja suuremad sarvloomad. Pidu algas ohverdamisega - kohalike elanike andide (vepsa zavet) jätmisega kabelisse. Nendeks olid marjad ja teised valminud viljad, munad, vill, kangatükid. Ohverdamisele järgnesid kiriklikud rituaalid, mida viis läbi vaimulik: ristikäik järve äärde, kus peeti palvus, ja vee õnnistamine. Pärast vee õnnistamist käisid pühal osalejad vees. Õnnistatud vees ujutati ka hobuseid ning pesti härgi ja lehmi. Edasi läksid Kuja elanikud kalmistule ja mälestasid lahkunud sugulasi.

Religiooniga võitlemise perioodil kabel Sornova järve ääres hävitati. Makabeipäeva tähistamine jätkus sellele vaatamata, see sai vaid uue keskuse, mis asus kalmistule lähemal. Püha pidamise traditsiooni kestmisest räägib kasvõi järgmine fakt. 14. augustil 2001. aastal, kui meie ekspeditsioon oli Kuja külastus välitöödel, sadas paduvihma. Olime kindlad, et pidu ei tule. Üksnes mõni ekspeditsioonis osaleja, nende seas ka mina, otsustas katkematule vihmale vaatamata minna kella üheteiskümneks kalmistule. Meie üllatuseks olid mõned Kuja elanikud selleks ajaks jõudnud seal juba ära käia. Ekstreemsetes tingimustes võtsid püha tähistamisest osa peamiselt vanemad naised lähedalasuvast Sontaga külast. Tavaliselt on sellest haaratud kõik vanuserühmad. 
Tänapäeval on makabeipäeva tähistamisel aktuaalseks muutunud teised rituaalid. Sel päeval algab inimeste vool kalmistule hommikul enne kümmet pärast kodust teejoomist. Esimestena tulevad Sontaga venelased ja Kiino vepslased, kella kaheteiskümneks jõuavad kohale kaugemal asuva vepsa küla Prangati elanikud. Kalmistul sooritatakse surnud sugulaste ja oma küla inimeste mälestamise rituaal, mis seostub inimestele rituaalse suhtlemisega ajutiselt kahe maailma vahel jagunenud suguvõsa ja külakogukonna liikmete vahel. Mälestamine koosneb haual kadunukese tervitamisest ja söömaajast. Söömalaual on tähtsal kohal esimesed viljad, mille maitsmise rõõmu tuleb jagada lahkunutega. Kujas on makabeipäeva mälestussöömajal erilise tähtsusega valminud mustikad või vaarikad, mida pannakse kalmule. Esimeste viljadena on kasutusel ka kartul ja tomatid, mis on vepsa küladesse jõudnud suhteliselt hilja (esimene umbes 19. sajandi lõpul, teine 20. sajandi esimesel poolel). Värskeid vilju täiendavad küpsetised: kartuliga kalitkad ja kalapirukad.

Mälestussöömaja jooksul on vepslastel igal pool säilinud tava kostitada sugulase hinge mälestuseks iga hauast mööduvat inimest, ka täiesti võorrast. Kombe kohaselt ei tohi sellisest kostitamisest keelduda. Sugulaste haudade külastamisele järgneb oma küla surnute mälestamine.

Järgmiseks tähtsaks rituaaliks tänapäeva makabeipäeva tähistamisel on ohvrite või tõotusteandide (zavet) toomine - kombetalitus, mida minevikus täideti ühena esimestest. Muutunud on koht, kuhu ande tuuakse. Kabeli asemel on selleks saanud Sornova järv. Pärast surnute mälestamist lähevad püha tähistajad järve äärde ja viskavad vette münte või lõngakerasid, kuhu on sisse pistetud marju. ${ }^{5}$ Viimane unikaalne ohverdamisviis tähendab ühest küljest sümboolset tänu Jumalale korilusandide ja karjakasvatuse sujumise eest, teisest küljest ka palvet, et tulevikus oleksid tagatud samasugused annid. Õigeusu pühamust (kabelist) lähima loodusobjekti juurde ümberpaigutumist ja loodusobjektile pühaduse omistamist võib täheldada ka teistes vepsa külades. Näiteks Päžaŕe külastus tõid inimesed jaanipäeval, karjakaitse tõotuspühal (24. juuni / 7. juuli), tõotusannid kabelisse. Pärast selle likvideerimist sai pühaks kohaks lähedal voolav oja, kuhu külaelanikud viskavad sel päeval münte (Karjala teaduskeskuse arhiiv, f 1, op 50, nr 679, lk 30-31). 
Informantide juttude kohaselt tähistavad Kuja elanikud samamoodi surnute mälestamisega kalmistul ja käiguga Sornova järve äärde spasan pei'd (1./19. augustil), mis on olemuselt patroonipüha, mille ametlik nimetus õigeusukalendris on meie Issanda, Jumala ja Päästja Jeesuse Kristuse muutmise püha. Tänapäeval võib makabei tõotuspüha läbiviimist Kuja vepsade juures võrrelda lõunavepsa omaga, aga spas'i patroonipüha sama pühaga Päžaŕe külastus.

Lõunavepslastel on makabeipäeva läbiviimise skeem enamvähem sama nagu Kuja elanikel, kuid paigutatuna teisele "geograafilisele kaardile" omandab püha mõningaid lokaalseid iseärasusi. Lõunavepslastel oli makabeipäeva tähistamise keskmeks Pölo pogost, mis kujutas varem endast administratiivset ja religioosset keskust, mis ühendas mitut külade pesa: Maigaŕ, Kortlaht, Požariš, Bušak, Saŕ, Tšäigi, Sodjäŕrv, Šidjäŕrv jt. Siin asus kaks kirikut: kivist (talvekirik) ja puust (suvine) ning kalmistu. Pogostis elasid kirikuteenijad ja tavalised talupojad. Kohalike elanike meenutuste kohaselt oli puukirik 1937. aastal veel olemas. 1978. aastal ei olnud Pölos alles enam ühtki elanikku.

Makabeipäeval toodi Pölo pogostisse palju hobuseid. Need ajasid "tõotuseks" kohale ümberkaudsete külade elanikud. Algas liturgia kirikus, millele järgnes vaimuliku juhitud ristikäik Pölo järve äärde ja vee pühitsemine risti vettekastmisega. Sellele järgnes inimeste ja kariloomade kümblemine vees. Paljud peremehed sõitsid vette bravuurikalt hobuse seljas ratsutades. Makabeipäeva suplus oli jooksva aasta viimane ujumine. Pärast kümblust hajus rahvas laiali haudadele ja mälestas surnuid. Pärast seda algasid Pölo pogosti juures pidustused. Praeguseks on Pölo pogostis säilinud üksnes kivikiriku varemed, mille kõrval asub kinnikasvanud kalmistu.

Vanasti tulid ümberkaudsete külade elanikud kohaliku kombe kohaselt nelipühade (troitsa) eel siia kalme korrastama. Praegu algab haudade korrastamine kalmistule tulekuga, kõige sagedamini püha ajal. Kombe muutumine on tingitud lõunavepslaste demograafilise olukorra muutumisest. Lõunavepsa külade elanikud on valdavalt 70 aastased ja vanemad. Neil on raske tulla jala 8-12 km kauguselt oma küladest Pölo pogostisse. Seepärast on tänapäeval makabeipäeval osalemine ja selle tähistamine seotud paljudel eakatel transpordiprobleemiga. Varem oli Novgorodi kubermangu vepslaste ja venelaste seas levinud veendumus, et pühasse kohta minek on Jumalale meelepärane 
tegu, seepärast tuleb selleks jõudu kulutada - minna jala. Nii leidub vürst Vjatšeslav Teniševi etnograafiabüroos (19. ja 20. sajandi vahetus) neist paigust pärit korrespondendilt selline teade: "Hobusega käimist peetakse suve ajal laiduväärseks, sest talupojad peavad jumalateenistusele siirdudes pühakute kummardamise kõrval silmas ka teelolekut ja vaevanägemist" (Gromõko \& Buganov 2000: 152). Vaatamata sellele, et see usulis-kõlbeline käitumisnorm on tuntud tänini ja mõned lõunavepsa eakad elanikud seda ka järgivad, on see sattunud vastuollu kaugel asuva püha koha külastamise võimalustega. 2002. aasta augustis, mil me uurisime lõunavepsa territooriumi, rõõmustas paljusid Pölo pogostist $8 \mathrm{~km}$ kaugusel elavaid Maigaŕe informante ootamatu võimalus saada pidustustele meie ekspeditsiooni bussiga.

Tervikuna näitasid pidustuste kohale koondunud liiklusvahendid ühest küljest "aja märki” - külaelanike kihistumist vanadeks ja vähekindlustatuteks ning nooremateks ja kindlustatumateks, teisest küljest pidustustel osalejaid, kelle seas oli palju selle paikkonna endisi elanikke, kes olid oma kunagisse kodukanti sõitnud isikliku autoga uuest elupaigast - Leningradi oblasti linnadest Boksitogorskist, Pikalevost, Tihvinist ja isegi Peterburist. Neist moodustus liigutav kokkutulek, mis andis tunnistust, et inimest kisub alati tagasi sinna, kus on möödunud tema lapsepõlv ja noorusaeg. Pühal käies ei juhindunud nad üksnes soovist näha sugulasi, sõpru, endisi külaelanikke, vaid ka püüdest näidata, et mäletavad ja austavad elust lahkunud pereliikmeid.

2002. aasta 14. augustil algas püha Pölo pogostis surnud sugulaste haudade koristamisega. Sellele järgnes surnute mälestamine söömisega. Meie vaatlused näitasid, et makabeipäeva toiduvalik oli lõuna- ja Kuja vepslastel pisut erinev. Lisaks üldlevinud küpsetistele, eelkõige kalapirukatele, sisaldab lõunavepslaste söömaaeg "esimese roana" kurke ja tomateid. Kindlasti juuakse ka alkoholi, iseäranis õlut, mida me ei näinud püha tähistamisel Kujas. Selles kombes väljendub õlletraditsiooni eriline vastupidavus lõunavepslastel, erinevalt teistest vepsa paiksetest rühmadest. 
Vepsa küla traditsioonilised pühad 20. ja 21. sajandi vahetusel 221

\section{Issandamuutmise päev (spas) Päžaŕe külastus}

Patroonipühade säilimise näiteks vepslaste tänapäeva eluolus on spasan pei, mida tänini tähistatakse 19. augustil (vkj 6. augustil) Vologda oblasti Babajevo rajooni Päžaŕe külastus. Juhtus nii, et mul õnnestus selle püha tähistamist jälgida kahel korral - 1997. ja 2001. aastal.

Ent alustagem minevikust (Karjala teaduskeskuse arhiiv, $\mathrm{f} 1$, op 50, nr 679, lk 31-32). Spas oli Päžaŕes kõige tähtsam püha. Sellesse külastusse kuulus vanasti üheksa väikest küla: Minatšagj, Vaśkinad, Palatez, Fenitši, Rand, Rod́k, Juišagj, Jeremagj ja Jogentaga. Püha tähistas õigeusu ajaloo kõige olulisemat sündmust - Issandamuutmist, mille auks kohalik kirik kandis Preobraženski kiriku nime. Püha tähistati kolm päeva.

Esimese päeva hommikul jõid kohalikud koos naaberasulatest saabunud külalistega teed koos erinevate küpsetistega. Kellade helina saatel siirdus rahvas alates väikestest ja lõpetades suurtega kirikusse. Selle püha jumalateenistuse iseärasuseks oli liturgiale järgnev kirikusse toodud valminud viljade (õunad, naerid jne) õnnistamine. Sellele järgnes lahkunud sugulaste mälestamine kiriku kõrval kalmistul. Pärast jumalateenistust algas ikoonidega ristikäik preestriga eesotsas. Selle kulgemine oli määratud traditsiooniliselt. Esimesel päeval käidi läbi kuue küla elanike kodud alates Minatšagjast kuni Rod́kini, teisel päeval oldi Juišagjas ning kolmandal Jeremagjas ja Jogenatagas. Samas järjekorras võeti vastu külalisi. Pidustuste iga päev lõppes guljanjega.

Nõukogude ajal püha kestvus järkjärgult vähenes. 1930. aastatel sündinud informandid rääkisid juba kaks päeva kestnud pidustustest. Praegu tähistatakse spas'i Päžaŕes üks päev. Kui see langeb pühapäevale, on see rahvarohkem külaliste tõttu, kes argipäeviti on tööl, peamiselt tullakse Pjaželkast, Kolašmast, Nižnjaja Nožemast ja rajoonikeskusest Babajevost. 1950. aastate lõpuni oli spas Päžaŕes märksa mastaapsem. Seda tulid tähistama ka praeguseks tühjaks jäänud asulate Śimǵäre, Nažamjäŕrve Vahtaŕe, Väräsäŕe ja Pelkaski elanikud.

Igal aastal algab spas'i hommik igas Päžaŕe peres teejoomise ja pirukatega, pühale saabunud külaliste vastuvõtmise ja kostitamisega. Seejärel suunduvad kõik pereliikmed ja külalised autodega, mootorratastega või jalgsi Preobraženski kirikusse ja seda ümbritsevale 
kalmistule. Inimesed käivad tingimata kirikus, millest praeguseks on alles ainult seinad, palvetavad ime läbi säilinud ikoonide juures, panevad küünlad, jätavad raha.

Edasi koguneb iga hõim surnud sugulase kalmu juurde, et teda mälestada. Video abil õnnestus näidata, et see hetk väljendab eriti selgelt sugulaste ühtsust, nad näevad välja nagu "tugev sugu", ühendades kõiki põlvkondi. Selle päeva mälestustoidul on püha spetsiifikast ja kohalikust vepsa traditsioonist tingitud eripärad. Sel päeval on väga tähtsal kohal õunad ja kurgid, aga ka mälestustoit munakürz - munakook, omleti erikuju. Pärast mälestamist algab kalmistul perekondade omavaheline suhtlemine. Seejärel läheb rahvas laiali kodudesse, algab pidupäeva lõuna ja külaskäimine.

\section{Kokkuvõtteks}

Issandamuutmise päevale pühendatud vepsa kohalike pühade (kaks tõotuspüha ja üks patroonipüha) analüüs näitas, et nad kujutavad endast omapärast ajastu peeglit, milles kajastuvad poliitilised, sotsiaalmajanduslikud, vaimsed ja etnilised eripärad rahvuse eluloos. Vaatamata kolme püha mõningatele piirkondlikele erinevustele sisaldavad nad ühtesid ja samu elujõulisi elemente, mis ei allu mingitele muutustele: peotoidu valmistamine, surnud sugulaste ja külaelanike mälestamine, sugulaste, naabrite ja kodukandi inimeste kohtumised ja külaskäigud.

Nende elementide põhjal võib määratleda traditsiooniliste pühade funktsioonid tänapäeva vepsa külas. Tänaseni on neil suur tähtsus. Nad on omamoodi emotsionaalne läbimurre hallis argipäevas. Tõotus- ja patroonipühad etendavad olulist stimuleerivat rolli perekonna tugevdamisel, küla ühendamisel, kodukandi ja lõppkokkuvõttes ka oma rahvusest hoolimise tekitamisel. Nende sidemete üks osa on lahkunud põlvede mäletamine. Selle uskumatu vastupidavus sajandite vältel annab tunnistust vepsa rahva tervetest kõlbelistest alustest. Aastatepikkuse uurimise vältel ilmnenud pühadetraditsiooni kestvus näitab: kuni elab vepsa küla, elavad ka selle pühad. Kuid külad surevad välja: vepsa noorsugu siirdub linna õppima ja tööle ega tule tagasi, tõsine probleem on joomine. Hädasti oleks vaja küla säilimisele suunatud hästi läbimõeldud sotsiaalmajanduslikku programmi, külaelu 
prestiiži tõstmist. Seda probleemi lahates kirjutas tuntud ajakirjanik Vassili Peskov Komsomolskaja Pravdas: "Kas miski meis liigahtab, kui mõtestame toimunu tagajärgi? Kui mitte, ei too saatus meile mitte midagi rõõmustavat." Ta toob sellise näite: "Jaapanlased, kes teenivad tööstuses suurt raha, maksavad oma talupoegadele riisi eest kaheksa korda rohkem kui maksab riis maailmaturul. Miks? Nad ei taha, et külades lakataks riisi kasvatamast, et inimesed ei jätaks maha toitjat maad - paljugi, mis võib homme juhtuda. Jaapanlastelt tuleb õppida mitte üksnes kõrgtehnoloogiat, vaid ka elutarkust mitte kaotada seda, mida on tingimata tarvis hoida." Tähtsat rolli võiks vepslaste seas kanda õigeusu teadmiste levitamine, mis oleks võimalik õigeusukiriku tegevuse taastamisel vepsa külades. Õigeusu väline taassünd algab kohalike kabelite ja kirikute, koguduseelu taastamisest. Kohalikud võimud ja kultuurikomisjonid peaksid mõtlema, millised oleksid võimalused aidata pühakodasid taastada ja korraldada neis kirikuteenistusi, alguses kasvõi episoodiliselt - pühade ajal.

\section{Vene keelest tõlkinud Asta Niinemets}

Originaal: Винокурова И. Ю. 2007: Традиционные праздники вепсской деревни на рубеже XX-XXI вв. Bепсы и этнокультурные перелены XX века. Studia Slavica Finlandensia. Tomus XXIV. Хельсинки: Institute for Russian and East European Studies, lk 187-209.

\section{Kommentaarid}

1 Käesoleva artikli tõlkes on kohanimede puhul kasutatud eelistatult vepsa teadaolevaid nimevariante vene omade asemel.

2 2001. aastal grant nr 5.1. - 0080 "Kompleksekspeditsioon Volga-Laadoga vesikonna vepslaste ja karjalaste lokaalsete rühmade uurimiseks" (juht V. Orfinski); aastail 2002-2003 grant EO281 "Iidsete vepslaste jälgedes (kompleksne ajaloolis-kultuuriline uurimus" (juht V. Orfinski). Pühade videosalvestused asuvad Karjala teaduskeskuse Keele, kirjanduse ja ajaloo instituudi fonogrammiarhiivis. 
${ }^{3}$ Sellest pühakohast lähemalt vt Vinokurova 1989: 121-122.

${ }^{4}$ Selle püha kohta vt lähemalt Vinokurova 1994: 87-90.

5 14. augustil 2001 seda rituaali halva ilma tõttu ei tehtud, mistõttu ei saanud seda ka jäädvustada.

\section{Kirjandus}

Birin 1989 = Бирин, В. Н. Демографическая ситуация у вепсов Карелии в 1950-1970-е годы. Пименов, В. В. (vast toim). Проблель истории и культуры вепсской народности. Петрозаводск: Карельский филиал AH CCCP, lk 43-54.

Gromõko \& Buganov $2000=$ Громыко, M. M. \& Буганов, А. В. О воззрениях русского народа. Москва: Паломник.

Malinovskaja 1930 = Малиновская, 3. П. Материалы по этнографии вепсов. Бартольд, В. В. (toim). Западноббинский сборник. Ленинград: Изд-во Академии наук СCCP, lk 163-200.

Mitrohhin 2005 = Митрохин, Л. Н. Религия в России и мире. Степин, В. С. $\&$ Гусейнов, А. А. (toim). Диалог культур в глобализирующелся лире: мировоззренческие аспекты. Москва: Наука.

Morev 1924 = Морев, Н. Старое и новое (Очерк из быта чухарей). Богорас, В. Г. (toim). Старый и новый был. Ленинград: Государственное издательство.

NVD 1957 = Nõukogude võimu dekreedid $=$ Декреть советской власти 1 . Москва.

Petuhhov $1989=$ Петухов, А. В. Административная разобщенность - фрактор ускорения ассимиляции вепсов. Пименов, В. В. (toim). Проблелиь истории и культуры вепсской народности. Петрозаводск: Карельский филиал АН CCCP, lk 55-63.

Ravdonikas 1926 = Равдоникас, В. И. Население. Равдоникас, В. И. (toim). Тихвинский край. Краеведческий сборник по Тихвинскому уезду. Тихвин, lk 237-261. 
Stepanov 1986 = Степанов, А. Я. На путях духовного восхождения. Религия и атеизл в Карелии. Петрозаводск: Карелия.

Strogalštšikova 1989 = Строгальщикова, З. И. Об этнодемографрических тенденщиях, социально-экономическом и культурном развитии вепсской народности. Пименов, В. В. (toim). Проблель истории и культурьь вепсской народности. Петрозаводск: Карельский фолиал АН СССР, lk 27-42.

Tšugunova 1989 = Чугунова, Н. “Оптина, завясь...”. О репрессиях против духовенства в 1918-1922. Огонек 34.

Tultseva 1985 = Тульцева, Л. А. Совреленные праздники и обряды народов СССР. Москва: Наука.

Vinokurova 1989 = Винокурова, И. Ю. Вепсские заветные праздники охраны скота. Пименов, В. В. (toim). Проблель истории и культурь вепсской народности. Петрозаводск: Карельский фрилиал АН СССР, lk 119-130.

Vinokurova 1994 = Винокурова, И. Ю. Календарные обычаи, обряды и праздники вепсов (конец XIX - начало XX в). Санкт-Петербург: Наука.

Vinokurova, Irina 1998. Äänisvepsäläisten kirkkopyhät: perinteet ja nykyaika. Hakamies, Pekka (toim). Ison karhun jälkeläiset. Helsinki: Suomalaisen Kirjallisuuden Seura, lk 99-118. 


\section{Summary}

\section{Traditional holidays in a Vepsian village at the turn of the 21st century}

Irina Vinokurova

Keywords: calendar customs, feast of the Transfiguration of our Lord, Maccabees' day, Vepsian

This article discusses the contemporary ethnoculture of the Veps and analyses the possible impact of heritage on the survival of the Veps. Under Socialism, the Veps' as well as other nations' traditional holiday cycle was influenced by the new social relationships that invaded their everyday life, leaving the former system on the verge of extinction. The article gives an overview of the intermediate impacts and offers, on the example of the analysis of the feast of the Transfiguration of our Lord, and the Maccabees' day, celebrated in some Vepsian villages until today, a description of the current situation of Vepsian sacramental vows and patron saint holidays, their functions and possible evolution. 


\section{Uurimusi vepsa rahvausust}

Koostaja ja toimetaja Madis Arukask

http://www.folklore.ee/rl/pubte/ee/sator/sator16/

ISSN 1736-0323 (veebiväljaanne)

ISBN 978-9949-544-96-7 (veebiväljaanne)

ISSN 1404-2011 (trükis)

ISBN 978-9949-544-95-0 (trükis)

DOI: 10.7592/Sator.2016.16

Tartu 2016

Sarja toimetaja: Mare Kõiva

Koostaja ja toimetaja: Madis Arukask

Keeletoimetaja: Asta Niinemets

Kaas ja kujundus: Andres Kuperjanov

Kaanefoto: Madis Arukask

Küljendus: Diana Kahre

HTML: Diana Kahre

Trükis ilmunud: Uurimusi vepsa rahvausust.

Koostaja ja toimetaja Madis Arukask. SATOR 16. Tartu 2016

Raamatu ettevalmistamist ja väljaandmist on toetanud Eesti Teadusagentuur (grandid nr 7385 ja 9271) ning Eesti Vabariigi Haridus- ja Teadusministeerium (projekt IUT 2-43). Raamatu toimetamist ja vormindamist toetas Euroopa Liit Euroopa Regionaalarengu Fondi kaudu (Eesti-uuringute Tippkeskus), see on seotud Eesti Teadusagentuuri institutsionaalse uurimisprojektiga IUT 22-5. Trükitud Eesti Kultuurkapitali toetusel.

E-raamatu valmimist toetas: EKKM14-344 Eesti keele, kultuuri ja folkloori kasutusalade laiendamine ja tutvustamine elektroonilistel infokandjatel.

(C) 2016 EKM Teaduskirjastus

(C) 2016 Eesti Folkloori Instituut

() 2016 EKM FO rahvausundi ja meedia töörühm

(C) 2016 autorid 